xo. 336

\title{
Reconnaissance during 1952 for Uranium-Bearing Carbonaceous Rocks in Parts of Colorado, Utah, Idaho, and Wyoming
}

By J. D. Vine and R. F. Flege, Jr.

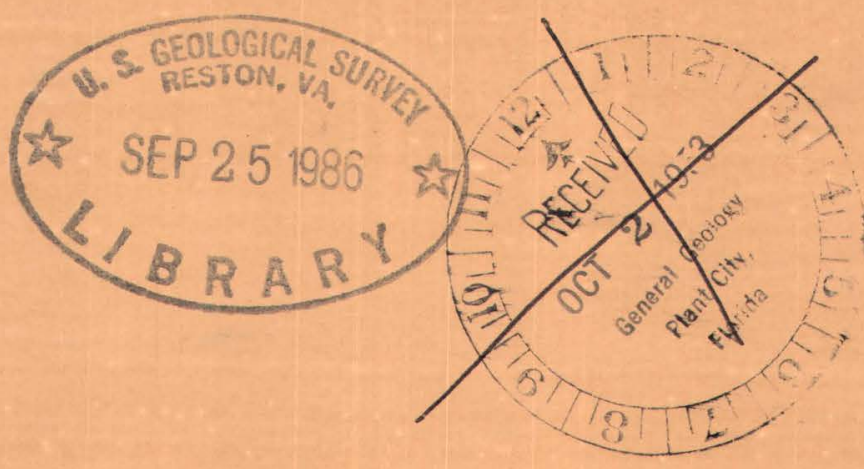

Trace Elements Investigations Report 336 TEI 336 A OTS D.20.

UNITED STATES DEPARTMENT OF THE INTERIOR GEOLOGICAL SURVEY 


\section{UNCLASSIFIED}

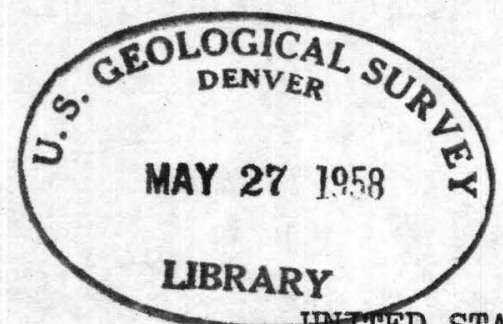

UNIIED STATES DEPARTMENT OF THE INTERIOR

RECONNAISSANCE DURING 1952 FOR URANIUM-BEARING CARBONACEOUS ROCKS IN PARTS OF COLORADO, UTAH, IDAHO, AND WYOMING*

By

James $D_{0}$ Vine and Robert $F$. Flege, Jr.

June 1953

Trace Elements Investigations Report 336

This preliminary report is dis. tributed without editorial and technical review for conformity with official standards and nomenclature. It is not for pubIic inspection or quotation.

*This report concerns work done on behalf of the Division of Raw Materials of the U. S, Atomic Energy Commission. 


\author{
USGS - TEI-336 \\ GEOLOGY AND MINERALOGY
}

Distribution (Series A)

No. of copies

American Cyanamid Company, Winchester. ............... Argonne National Laboratory. ....................... Atomic Energy Commission, Washington . . . . . . . . . . . . . . Battelle Memorial Institute, Columbus, . . ............. Carbide and Carbon Chemicals Company, Yol2 Area. . . . . . . . . Division of Raw Materials, Butte .................. . Division of Raw Materials, Denver. . . . . . . . . . . . . . . Division of Raw Materials, Grants. . ................ Division of Raw Materials, Hot Springs ................ . Division of Raw Materials, New York。. . . . . . . . . . . . . . . . Division of Raw Materials, Richfield ................ Division of Raw Materials, Salt Lake City. . . . . . . . . . . . . Dirision of Raw Materials, Washington, ................ Dow Chemical Company, Pittsburg. . . . . . . ......... Exploration Division, Grand Junction Operations Office........ Grand Junction Operations Office ................... Technical Information Service, Oak Ridge . . . . . . . . . . . Tennessee Valley Authority, Wilson Dam ................

U. S. Geological Survey:

Alaskan Geology Branch, Washington.................. Frels Branch, Washington, . . . . .................. Geochemistry and Petrology Branch, Washington. . . . . . . . . . Geophysies Branch, Washington, . . . ................. Mineral Deposits Branch, Washington. ................. E. H. Bailey, San Francisco, . . . . . . . .............. J. R. Cooper, Denver ........................... $\mathbb{N}_{6} M_{0}$ Denson, Denver 。. . . . . . . . . . . . . . . . . . . . . . . . C. E. Dutton Madison. .........................

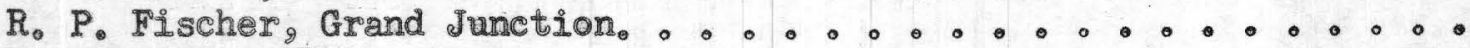
I. S. Gardner, Albuquerque . . . . . . . . . . . . . . . . . . 1

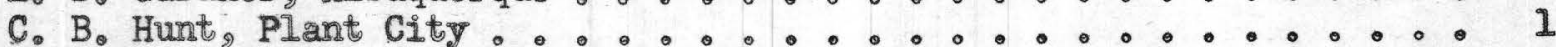
M. $R_{0}$ Klepper, Washington. . . . ............... 1

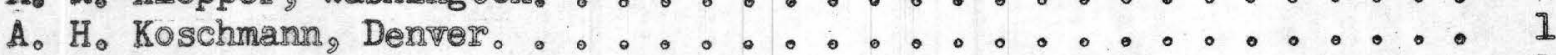
R. A. Lavrence, Knoxville, . . . . . ................. 1 D. Mo Lemmon, Washington . . . . . . . . . . . . . . . . . . 1 J. $D_{0}$ Love, Laramie. . . . . . . . . . . . . . . . . . . . . . . 1 K. I. Buck, Denver . . . . . . . . . . . . . . . . . . . . . . . 1

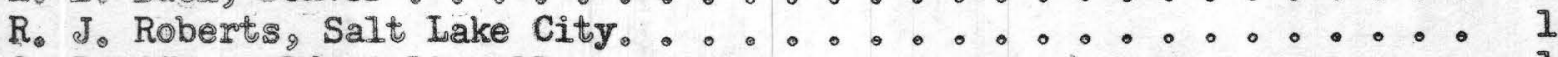
Q. D. Singewald, Beltsville. . . . . . . . . . . . . .... 1 J. F. Smith $J_{1}$, Denver . . . . . . . . . . .......... 1 R. W. Swansong Spokane ......................... 1 A. E. Weissenborn, Spokane . . . . . . . . . . .......... I W. $P_{0}$ Williams, Joplin . . . . . . . . . . . . . . ........ 1 $\mathrm{TEPCO}_{2}$ Washington:

Resource Compilation Section .... . . . . . . . . . . . . . . Reports Processing Section 


\section{CONTENTS}

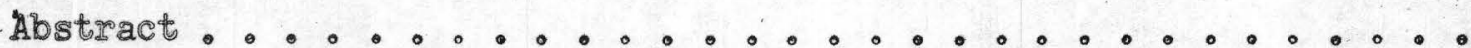

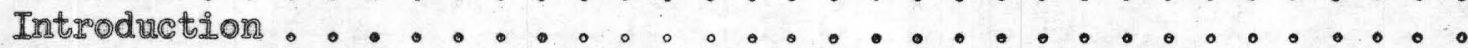

Description of selected areas examined ...............

Salmon area, Lemhi County, Idaho................

Driggs area, Teton and Bonneville Counties, Idaho ........

Caribou Mountains and adjacent areas, Bonneville County, Idaho and Iincoln County, Wyoming. .................

Auburn area, Lincoln County, Wyoming. .............

Evanston area, Uinta County, Wyoming. .............

Burnt Fork area, Sweetwater County, Wyoming ...........

Vernal area, Uintah County, Utah. ..............

Conclusions。 . . . . . . . . . . .............

Plans. $0.0 .0 .0 . . . .0 .0 .0 .0 .0 .0 .0 .0 .0 .0 .0$

Literature cited . . . . . . . . . ...............

Unpublished reports. . . . . . . . . . . . . . . . . . . . . . . . Appendix - Tabulation of analytical data

Table 1. Samples of coal, carbonaceous shale, and carbonacoous

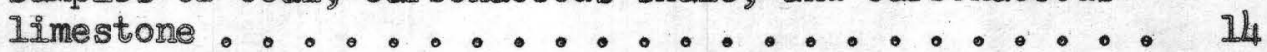

2. Samples of bituminous sandstone .......... 17

3. Samples of volcanic and miscellaneous rock types.... 17

4. Samples of water. ...............

\section{ILLUSTRATIONS}

Figure 1. Localities examined during reconnaissance for uranium in carbonaceous rocks in parts of Colorado, Utah, Idaho and Wyoming, $1952 \ldots \ldots \ldots$

2. Sketch map showing location of samples from the Burnt Fork area, Sweetwater County, Wyoming .......... 
RECONNAISSANCE DURING 1952 FOR URANIUM-BEARING CARBONACEOUS ROCKS IN PARTS OF COLORADO, UTAH, IDAHO, AND WYOMING

By

James D, Vine and Robert F. Flege, Jr。

ABSTRACT

A reconnaissance for uranium-bearing carbonaceous rocks was made during the 1952 field season in 23 areas in Colorado, Utah, Idaho, and Wyoming. Uranium in small amounts occurs in several of the areas examined, but no deposits were found that might have commercial possibilities. As much as 0.03 percent uranium is in the ash of coal in the Caribou Mountain area in southeastarn Idaho; 0.012 percent in the ash of coal in the Burnt Fork area of southwestern Wyoming: and 0.009 percent in the ash of coal from near Driggs in eastern Idaho. Seven additional areas were examined in which beds of coal or carbonaceous shale contained more than 0.002 but less than 0.007 percent uranium in the ash. Unweathered samples of bituminous sandstone from the Vernal area, Utah, contain minor quantities of uranium。

\section{INTRODUCTION}

A reconnaissance was done during the 1952 field season for uraniumbearing carbonaceous materials in 23. areas of Colorado, Utah, Idaho, and Wyoming by the U. S. Geological Survey on behalf of the Division of Raw Materials of the Atomic Energy Commission. This study was a continuation of the reconnaissance during the 1951 field season reported by Vine and Moore (1952). . 
Only those areas that may contribute to future studies on the occurrence of uranium in carbonaceous rocks are discussed in this report. A complete tabulation of all analytical data resulting from the work, however, is listed In the appendix, Chemical analyses and radioactivity measurements were made at U. S. Geological Survey Laboratories at Denver and Washington, D, C.

\section{DESCRIPTION OF SELECTED AREAS EXAMINED}

SaImon area, Lemhi County, Idaho

Coal in the Germer member of the Challis rolcanics of probable Oligocene or Miocene age was examined at a mine about 2 miles west of Salmon, Lemhi County, Idaho (1oc, 1, figొ 1). Openings have been made in two zones of coal and carbonaceous shale at this mine, but no significant radioactivity was detected in either zone. A grab sample (VI-1264) from the upper of two dumps at this mine contained 0.002 percent uranium in the ash and 41.0 percent ash. (See Appendix, table 1.) Because no radioactivity was detected at the mine entries no attempt was made to trace the coal beds laterally.

\section{Droiggs area, Teton and Bonneville Counties, Idaho}

Coal believed to be from the Bear River formation of Cretaceous age and containing small quantities of uranim, was collected at two localities in the Driggs area, Teton and Bonneville Counties, Idaho. A sample of coal (sample VI-1153) from the dump of an abandoned mine in the Horseshoe district about 12 miles west of Driggs contained 0,003 percent uranium, 36,2 percent ash, and 0.009 percent uranium in the ash. A sample of coal (sample VI-1149) from the dump of an abandoned mine on Pine Creek Pass about 13 miles southwest of Driggs contained 0.002 percent uranium, 50 percent ash, and 0.003 


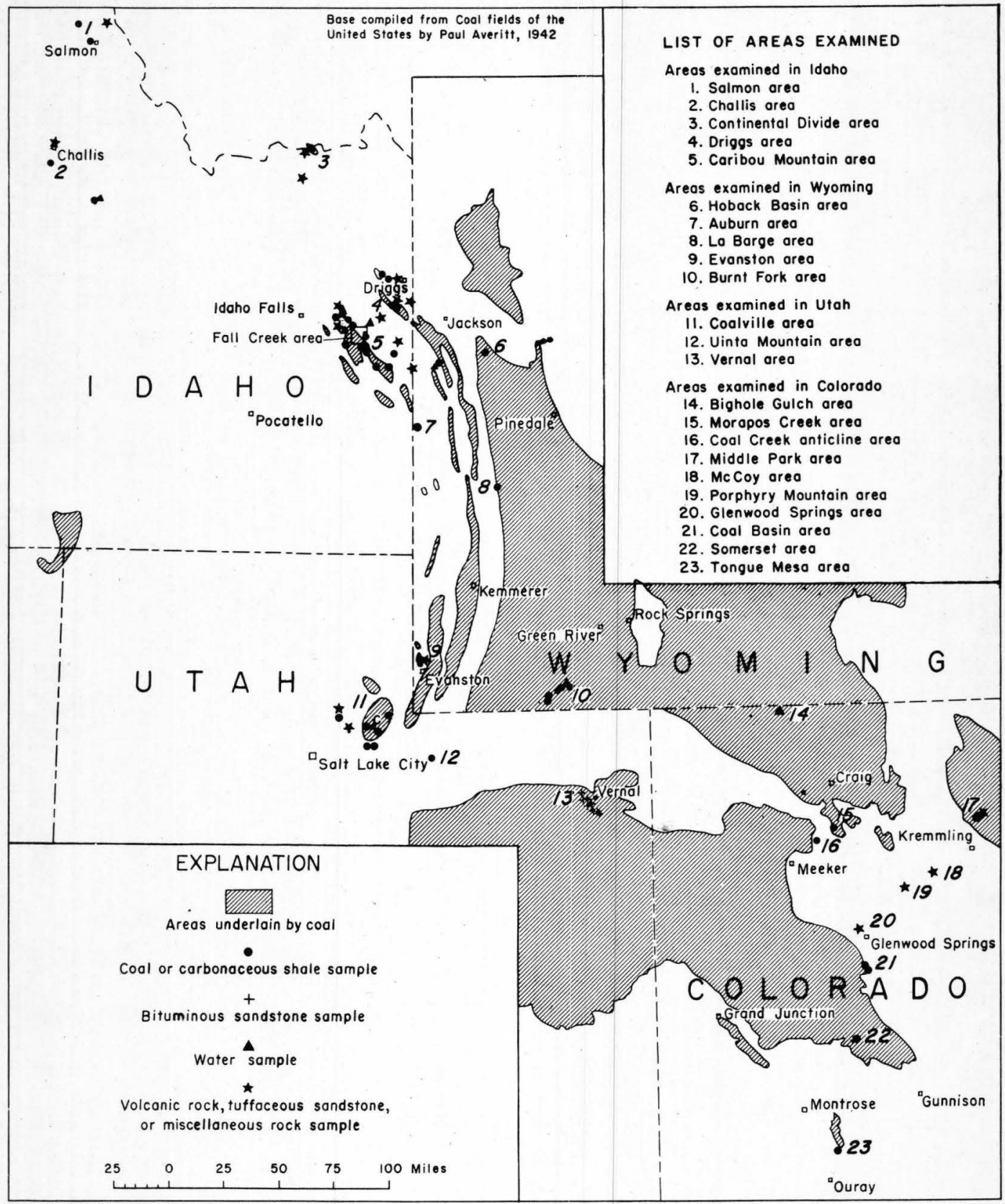

FIGURE I. LOCALITIES EXAMINED DURING RECONNAISSANCE FOR URANIUM IN CARBONACEOUS ROCKS IN PARTS OF COLORADO, UTAH, IDAHO, AND WYOMING 1952 
percent uranium in the ash.

Coal believed to be in the Frontier formation of Cretaceous age was sampled at an abandoned coal prospect on Rainy Creek about 2 miles southeast of the PIne Creek Pass locality. A grab sample of coal from the dump (sample VI-1150) contained 0.001 percent uranium in the sample, 33.9 percent ash, and 0.003 percent uranium in the ash.

Caribou Mountains and adjacent areas, Bonneville County, Idaho and Iincoln County, Wyoming

Reconnaissance for uranium-bearing coal in the Caribou Mountains and adjacent areas was done in an attempt to extend the area of known uraniumbearing rocks described at the Fall Creek coal prospect by Vine and Moore (1952). Slight radioactivity was detected at most localities where the zone of carbonaceous rocks containing uranium at the Fall Creek coal prospect covld be recognized. Considerable difficulty was encountered, however, in finding fresh exposures of this zone for sampling. At some localities it was possible only to collect samples of dark radioactive soils or boulders of carbonaceous limestone float believed to be derived from the same zone of radioactive carbonaceous rocks exposed at the Fall Creek prospect. These samples, including the soil samples, are useful in determining the distribus tion of the radioactive strata. Carbonaceous limestone (sample VI-1045) containing 0.005 percent uranium was found near the northern end of the Caribou Mountains. Coal exposed in a fresh road cut on Elk Creek (sample VI-1173) contains 0.0033 percent uranium. Selected coal on the dump of the abandoned Croley coal prospect (sample VI-1140) contains 0.007 percent uranilum in the sample, 21.7 percent ash, and 0.03 percent uranium in the ash. The top 9 inches of impure coal (sample VI-1066) from a 36-inch carbonaceous 
zone exposed along a road cut north of Grays Lake contains 0.013 percent uranium, 69.9 percent ash, and 0.019 percent uranium in the ash. These analyses Indicate that the carbonaceous rocks of the Bear River formation contain small quantities of uranium over a widespread area.

\section{Auburn area, Lincoln County, Wyoming}

Coal on the dump at an abandoned prospect believed to be in the Bear River formation was examined and sampled about a mile west of Auburn, lincoln County, Wyo. A grab sample (VW-1190) contained 0.0035 percent uranium in the sample, 88.01 percent ash, and 0.0053 percent uranium in the ash.

\section{Evanston area, Uinta County, Wyoming}

A thin bed of carbonaceous shale from the Evanston formation of Paleocene age was examined about a mile ast of Almy. A grab sample (VW-1180) contained 0,005 percent equivalent uranium and 0.004 percent uranium.

\section{Burait Fork area, Sweetwater County, Wyoming}

A reconnaissance was made for uranium-bearing carbonaceous rocks in the Bridger formation of Eocene age near Burnt Fork in southwestern Sweetwater County, Wyo. (See fig. 2.) Four coal beds ranging in thickness from 6 to 24 inches were examined in the north bank of Henrys Fork, but they were not radioactive. Stratigraphically above these main coal beds, however, a thin zone of radioactive coaly shale whs found. Thin lenses of powdery coal or coaly shale as much as 2 inches thick, interbedded with carbonaceous shale and clay, formed radioactive zone as much as 3 feet thick. This zone was traced for a distance of about 12 miles in the hope of finding a locality 


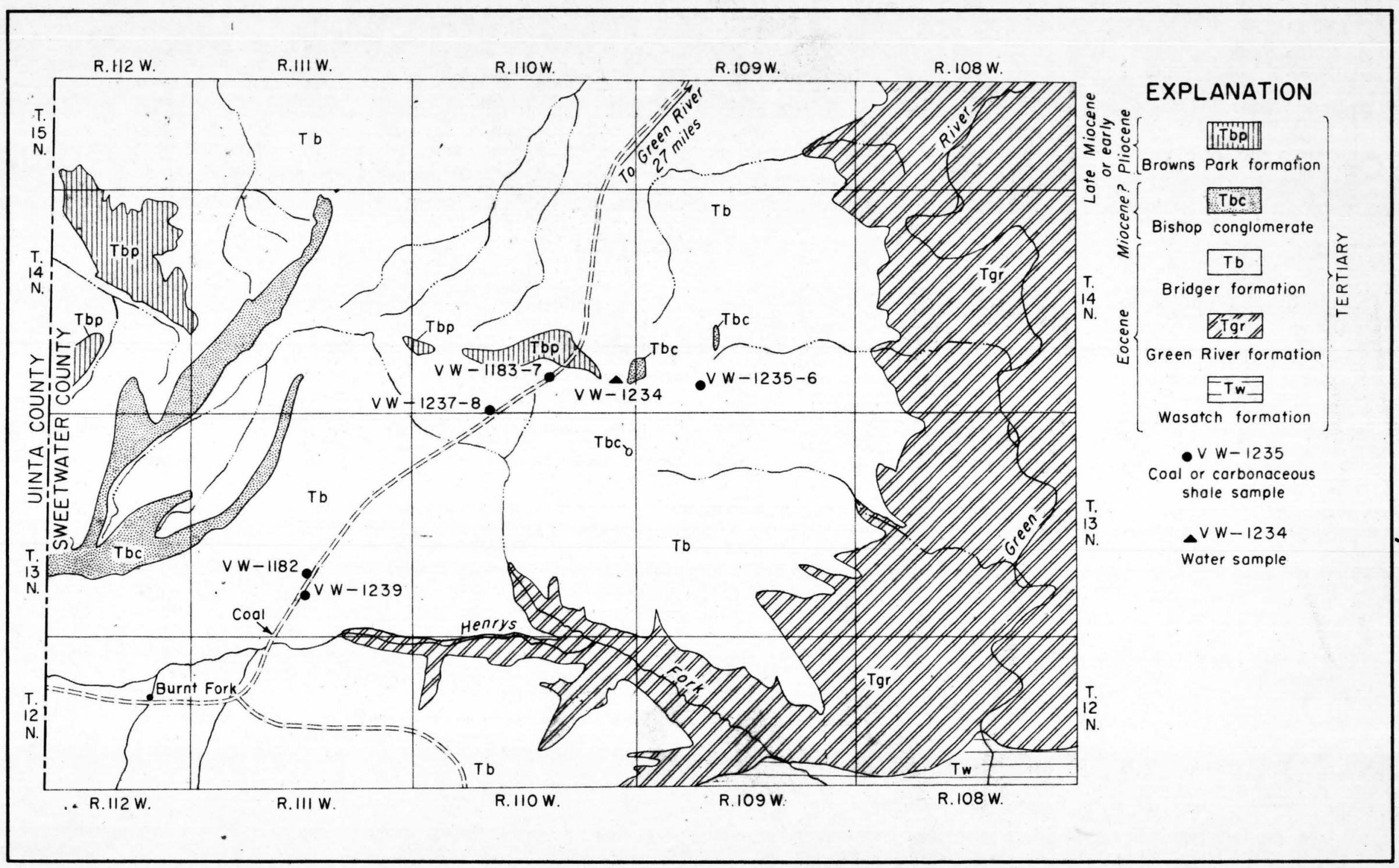

Geology after W. H. Bradley

FIGURE 2:--SKETCH MAP SHOWING LOCATIONS OF SAMPLES FROM THE BURNT FORK AREA, SWEETWATER COUNTY, WYOMING 
where It would be thicker and higher in grade. Ten samples (VW-1183 to 1187 and 1235 to 1239) were collected from the radioactive zone. The highest uranium content of any of these samples was a selected grab sample that contained 0.007 percent equivalent uranium, 0.007 percent uranium, 54.8 percent ash, and 0.012 percent uranium in the ash. This deposit has no commercial possibilities but is noteworthy because of the geologic setting and may provide encouragement for further search in adjoining areas. This radios active zone is the stratigraphically highest zone of carbonaceous material below the Bear Mowntain erosion surface of Bradley. (1936), which is overlain by the tuffaceous sandstones of the Browns Park formation. The Browns Park formation in the Miller Hill area, Wyo. (Love, 1953) contains deposits of uranium and is believed to contain potential source beds for uranium.

Vernal area, Uintah County, Utah

A sample of bitumen collected in 1951 from an abandoned bituminous sandstone quarry west of Vernal, Utah, gave sufficiently encouraging results (Vine and Moore, 1952, p. 18) that the area was revisited in 1952 to collect a representative suite of samples. Twelve samples were collected from eight localities at various points along the greater part of the length of Asphalt Ridge described by Spieker (1930). Most of the samples were collected from abandoned prospect pits, abandoned quarries, or natural outcrops where the bituminous material has been oxidilzed to a black nearly solid mass with the Riscosity of a cold tar. One wnweathered sample was collected from the working face of the Uiatah County Highway quarry. At the working face the sandstone is friable, and the mass is easily molded in the hand. Each sand grain is loosely held in place by the bituminous material which has the 
consistency of a heavy grease. In order to obtain uniform and comparable results, Wendell P. Tucker of the U. S。 Geological Survey laboratory in Washingtor, $D_{0}$ C. extracted the oil from the inorganic material in each sample by a process of continuous leaching with carbon disulfide. The uranium content of samples thus treated ranges from 0.00002 to 0.0006 percent uranium in the oil and from 0.00048 to 0.026 percent uranium in the ash of the oil. Some of the weathered samples contain the most uranium, indicating perhaps that the concentration of uranium may be a surface phenomena, and that the Lower concentrations may be more representative of the bituminous sandstone. The unweathered sample obtained from the working face of the county highway quarry was one of the lowest in uranium content having only 0.00004 percent uranium in the oil and 0,00048 percent uranium in the ash.

\section{CONCLUSIONS}

No new deposits of commercial size and grade were found in any of the 23 areas examined. In many of the areas, exposures of bedrock were so poor as to make an appraisal difficult. Coal and carbonaceous materials commonly are exposed in old prdspect pits or can be seen only on abandoned mine dumps, thus providing little opportunity to sample the carbonaceous rocks where geologic relationships seem most favorable for the concentration of uranium. of the areas investigated, therefore, few can be definitely ruled out as having no further potentialities for uranium.

Uranium-bearing carbonaceous rocks in the Bear River formation were examined and sampled over a widespread area in southeastern Idaho and adjao cent parts of Wyoming and in the Bridger formation in the Burnt Fork area of southwestern Wyoming. The small amounts of uranium found may indicate that 
deposits of higher grade are present in these areas.

The bituminous sandstone examined near Vernal, Utah contains minor quantities of uranium。

\section{PLAANS}

Further investigations of these occurrences are not planned at the present time. However, additional reconnaissance of the Bear River formation in Idaho and Wyoming will be made at the first opportunity. 


\section{LITERATURE CITED}

Averitt, $P_{\circ}, 1942$, Coal fields of the United States: U, S. Geol. Survey map, $1: 2,500,000$.

Bradley, W. H. . 1936, Geomorphology of the north flank of the Uinta Mountains: U. S. Geol. Survey Prof. Paper 185 I, pp. 163 to 204.

Speiker, E. $\mathrm{M}_{\circ}, 1930$, Bituminous sandstone near Vernal, Utah: U. S, Geol. Survey Bull. $822 \circ C_{2}$ pp. $77 \circ 98$.

Vine, J. $D_{0}$ and Moore, $G_{0} W_{0}, 1952$, Occurrence of uraniumbearing coal, carbonaceous shale and carbonaceous limestone in the Fall Creek area ${ }_{2}$ Bonneville County, Idaho: U.S.Geol. Survey Circular 212.

\section{UNPUBLISHED REPORTS}

Love, J. $D_{0}, 1953$, Preliminary report on the uranium deposits in the Miller Hill area, Carbon County, Wyoming: U。 S. Geol, Survey Trace Elements Inv. Rept. 315.

Vine, Jo $D_{0}$ and Moore, G. Wo 1952 , Reconnaissance for uranium-bearing carbonaceous rocks in northwestern Colorado, southwestern Wyoming, and adjacent parts of Utah and Idaho: U. So Geol. Survey Trace Elements Inv. Rept. 281. 
APPENDIX

Chemical analyses and radioactivity measurements were by $G_{0}$. W. Boyes, J. Budinsky, Mo Delevause, R。 Dufour, S. P. Furman, C. A。 Horr, C. Hoy, H. Levine, So Lundine, B. A. McCall, W. Mountjoy, Wo Wo Niles, A, Pietsch, $H_{0}$ Potersong and $W_{0}$ P. Tucker.

\section{TABULATION OF ANALYTICAL DATA}

Table $1_{0}$--Samples of coal, carbonaceous shale, and carbonaceous limestone

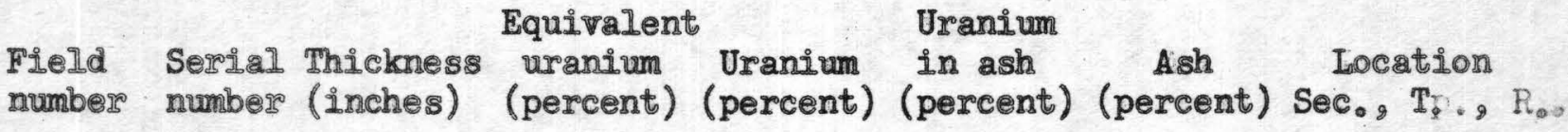

Salmon area, Lemhi County, Idaho

\begin{tabular}{|c|c|c|c|c|}
\hline $\begin{array}{l}\text { VI- } 1164 \\
V I-1165\end{array}$ & $\begin{array}{l}95493 \\
95494\end{array}$ & $\begin{array}{l}\text { Gral } \\
\text { Gral }\end{array}$ & $\begin{array}{l}0.003 \\
0.005\end{array}$ & $\begin{array}{l}0.001 \\
0.003\end{array}$ \\
\hline
\end{tabular}

Challis area, Custer County, Idaho

$\begin{array}{rrllllrr}\text { VI-1160 } & 95490 & \text { Grab } & 0.000 & \infty & \infty & 77.8 & 7-12 \mathrm{~N}-19 \mathrm{E} \\ \text { VI-1161 } & 95491 & \mathrm{Grab} & 0.000 & \infty & \infty & 6.2 & 28-10 \mathrm{~N}-22 \mathrm{E} \\ \text { VI-1162 } & 95492 & \mathrm{Grab} & 0.002 & \infty & \infty & 95.3 & \text { " }\end{array}$

Continental Divide area, Clark County, Idaho

\begin{tabular}{|c|c|c|}
\hline $\begin{array}{l}\text { VI-1078 } \\
\text { VI-1079 }\end{array}$ & $\begin{array}{l}90183 \\
90184\end{array}$ & $11-\frac{14 N-38 E}{m}$ \\
\hline
\end{tabular}

Driggs area, Teton and Bonneville Counties, Idaho

\begin{tabular}{|c|c|c|c|c|c|c|c|}
\hline VI-1093 & 90189 & Grab & 0.003 & $\infty$ & $\infty$ & 63.5 & $25-3 \mathrm{~N}=4 \mathrm{4} / 4 \mathrm{E}$ \\
\hline VI-1094 & 90199 & Grab & 0.001 & $\infty$ & $\infty$ & 58.5 & n \\
\hline VI-1095 & 90200 & Grab & 0.001 & $\infty$ & $\infty$ & $\infty$ & ne \\
\hline$V I=1149$ & 95484 & Grab & 0.002 & 0.002 & 0.003 & 50.0 & " \\
\hline$V I=1150$ & 95485 & Grab & 0.001 & 0.001 & 0.003 & 33.9 & $5-2 N-45 E$ \\
\hline VI-1153 & 95486 & Grab & 0.003 & 0.003 & 0.009 & 36.2 & $32-5 \mathrm{~N}-44 \mathrm{E}$ \\
\hline VI- 1154 & 95487 & Grab & 0.000 & $\infty$ & -0 & 79.0 & n \\
\hline VI -1155 & 95488 & Grab & 0.003 & $\infty$ & $\infty$ & 88.1 & $25-5 N-43 E$ \\
\hline VI-1156 & 95489 & Grab & 0.000 & $\infty$ & $\infty$ & 9.4 & " \\
\hline
\end{tabular}


Table 1, - Samples of coal, carbonaceous shale, and carbonaceous limestone (cont,)

Equivalent Uranium

Field Serial Thickness uranium Uranium in ash Ash Location numbers number (inches) (percent) (percent) (percent) (percent) Sec., Tr., K..

Caribou Mountains and adjacent areas, Bonneville County, Idaho and Lincoln County, Wyoming

\begin{tabular}{|c|c|c|c|c|c|c|c|}
\hline VI-1044 & 87721 & Grab & 0.003 & $\infty$ & $-\infty$ & 61.7 & $13-1 \mathrm{~N}-4 \mathrm{IE}$ \\
\hline VI-1045 & 87722 & Grab & 0.006 & 0.005 & 0.008 & 59.6 & $2-1 \mathrm{~N}-4 \mathrm{IE}$ \\
\hline$V I=1046$ & 87723 & Grab & 0.002 & - & $\infty$ & 81.6 & ต \\
\hline VI-1065 & 88016 & Grab & 0.000 & $\infty$ & $\infty$ & $-\infty$ & $17-2 S-43 E$ \\
\hline VI-1066 & 88017 & top $9^{18}$ & 0.011 & 0.013 & 0.019 & 69.9 & $23-3 S-43 E$ \\
\hline VI-1067 & 88108 & $9^{99}$ & 0.006 & 0.006 & 0.007 & 81.6 & ip \\
\hline VI-1068 & 88109 & $9^{18}$ & 0.005 & 0.005 & 0.006 & 83.1 & $n$ \\
\hline VI-1069 & 88110 & bottom $9^{17}$ & 0.006 & 0.007 & 0.009 & 79.9 & p \\
\hline VI=1070 & 88111 & $12^{10}$ & 0.001 & $\infty$ & $\infty$ & 82.4 & $24-3 S-44 E$ \\
\hline VW-1082 & 902487 & Grab & 0.003 & $\infty$ & $\infty$ & $-\infty$ & $4-37 \mathrm{~N}-117 \mathrm{~h}$ \\
\hline$V W=1083$ & 90188 & $12^{\mathrm{Bg}}$ & 0.001 & $-\infty$ & $\infty$ & 91.9 & $\because$ \\
\hline$V W=1084$ & 90189 & $14^{87}$ & 0.000 & $\infty$ & $\infty$ & 85.7 & 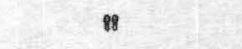 \\
\hline VI-1098 & 90203 & Grab & 0.000 & $\infty$ & $\infty$ & $-\infty$ & $7-1 S-43 E$ \\
\hline $\mathrm{VI}-1140$ & 95476 & Grab & 0.005 & 0.007 & 0.030 & 21.7 & $27-15-4 I E$ \\
\hline VI-114I & 95477 & Grab & 0.003 & 0.002 & 0.004 & 48.6 & PQ \\
\hline VI $=1170$ & 95499 & Grab & 0.001 & $-\infty$ & $\infty$ & 70.1 & $34-2 \mathrm{~N}-4 \mathrm{OE}$ \\
\hline VI-1I7I & D74323 & Grab & 0.003 & 0.0015 & 0.0012 & 74.65 & : \\
\hline VI-1172 & D74324 & Grab & 0.003 & 0.0019 & $\infty$ & $\infty$ & a \\
\hline VI-1173 & D74325 & Grab & 0.004 & 0.0033 & 0.0042 & 77.53 & $18-2 S-45 E$ \\
\hline VI-1174 & D74326 & Grab & 0.002 & 0.0011 & $\infty$ & $\infty$ & ? \\
\hline
\end{tabular}

Hoback Basin area, Sublette County, Wyoming

VW-1178 D74330 $12^{\text {pr }}$

$0.003 \quad 0.0015$

$0.0013 \quad 90.85$

$20-38 \mathrm{~N}-113 \mathrm{~W}$

Auburn area, Iincoln County, Wyoming

WW-1190 D74342 Grab

0.004

0.0035

$0.0053 \quad 88.01$

$5-32 N-119 W$

LaBarge area, Sublette County, Wyoming

VW-1177 D74329 12"

0.000

0.0016

0.0028

36.87

$1-28 \mathrm{~N}-114 \mathrm{~W}$

Evanston area, Uinta County, Wyoming

$\begin{array}{lllllll}\text { VW-1180 D74332 Grab } & 0.005 & 0.0040 & 0.0068 & 79.45 & 30-16 \mathrm{~N}-120 \mathrm{~W}\end{array}$ 
Table $1_{0}$-osamples of coal, carbonaceous shale, and carbonaceous limestone (cont.)

Equivalent

Field Serial Thickness uranium Uranium in ash

numbers number (inches) (percent) (percent) (percent) (percent) Sec, , Tp., $R_{\bullet}$.

Burnt Fork area, Sweetwater County, Wyoming

\begin{tabular}{|c|c|c|c|c|c|c|c|}
\hline VW-1182 & D74334 & Grab & 0.003 & 0.0013 & 0.0026 & 89.16 & $28-13 \mathrm{~N}-111 \mathrm{~W}$ \\
\hline$V W-1183$ & D74335 & top $4^{\text {ng }}$ & 0.004 & 0.0032 & 0.0055 & 70.78 & $27-14 \mathrm{~N}-110 \mathrm{~W}$ \\
\hline VW-1184 & D74336 & 698 & 0.007 & 0.0018 & $-\infty$ & $-\infty$ & pet \\
\hline$V W=1185$ & D74337 & $11^{91}$ & 0.003 & 0.0038 & 0.0048 & 86.03 & " \\
\hline VW-1186 & D74338 & bottom $11^{19}$ & 0.005 & 0.0034 & 0.0047 & 88.23 & " \\
\hline VW-1187 & D74339 & Grab & 0.005 & 0.0053 & 0.0081 & 82.16 & " \\
\hline VW-1235 & 101059 & Grab & 0.003 & $-\infty$ & - & 86.4 & $32-14 \mathrm{~N}-109 \mathrm{~W}$ \\
\hline VW-1236 & 101060 & Grab & 0.007 & 0.007 & 0.012 & 54.8 & 89 \\
\hline$V W=1237$ & 101061 & $12^{81}$ & 0.004 & 0.002 & 0.003 & 63.8 & $33-14 \mathrm{~N}-110 \mathrm{~W}$ \\
\hline$V W=1238$ & 101062 & Grab & 0.002 & 0.003 & 0.008 & & B \\
\hline VW=1239 & 101063 & Grab & 0.002 & $-\infty$ & $\infty$ & 58.9 & $27-13 \mathrm{~N}-111 \mathrm{~W}$ \\
\hline
\end{tabular}

Coalville area, Summit and Morgan Counties, Utah

$\begin{array}{llllllll}\text { WU-1022 } & 85726 & \mathrm{Grab} & 0.002 & 0.001 & 0.003 & 30.9 & 33-1 \mathrm{~N}-5 \mathrm{E} \\ \text { WU-1023 } & 85727 & 18 \% & 0.000 & -\infty & -\infty & 21.5 & 33-1 \mathrm{~N}-5 \mathrm{E} \\ \text { WU-1024 } & 87701 & \mathrm{Grab} & 0.003 & -\infty & - & 84.1 & 26-2 \mathrm{~N}-5 \mathrm{E} \\ \text { WU-1025 } & 87702 & \mathrm{Grab} & 0.003 & \infty & - & 86.6 & 18-2 \mathrm{~N}-5 \mathrm{E} \\ \text { WU-1027 } & 87704 & \mathrm{Grab} & 0.003 & -\infty & -\infty & 94.0 & 31-3 \mathrm{~N}-3 \mathrm{E} \\ \text { WU-1029 } & 87706 & \mathrm{Grab} & 0.002 & -\infty & -\infty & 65.5 & 26-3 \mathrm{~N}-6 \mathrm{E}\end{array}$

Morapos Creek area, Rio Blanco County, Colorado

VC-1009 85725 Grab $0.003 \quad \ldots \quad \ldots \quad 60.2 \quad 24-3 \mathrm{~N}-91 \mathrm{~W}$

Coal Creek anticline area, Rio Blanco County, Colorado

$\begin{array}{llllllll}\text { VC-1006 } & 85722 & \text { Grab } & 0.086 & 0.12 & 0.16 & 71.1 & 22-2 N-92 W \\ \text { VC-1007 } & 85723 & \text { Grab } & 0.06 & 0.064 & -\infty & \ldots & 0\end{array}$

Middle Park area, Grand County, Colorado

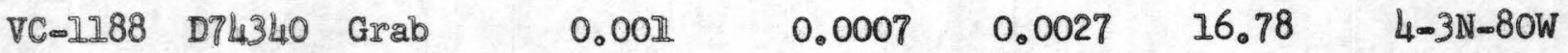

Coal Basin area, Pitkin County, Colorado

\begin{tabular}{|c|c|c|c|c|c|}
\hline VC- -1225 & 10105 & Grab & 0.002 & $-\infty$ & $\infty$ \\
\hline VC.1226 & 101058 & Grab & 0,001 & 0.00 & \\
\hline
\end{tabular}

Somerset area, Gunnison County, Colorado

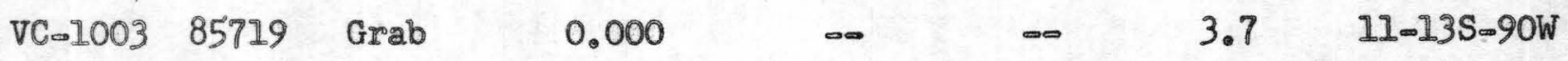


Table $1_{0}--$ Samples of coal, carbonaceous shale, and carbonaceous limestone (cont.)

Equivalent

Field Serial Thickness uranium Uranium in ash

number number (inches) (percent) (percent) (percent) (percent) Sec., Tp., $R_{0}$

Tongue Mesa area, Ouray County, Color ado

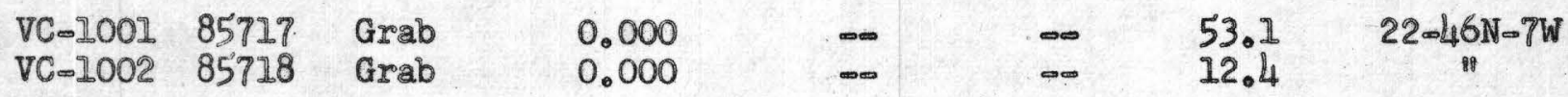

Table 2.oosamples of bituminous sandstone

Field Serial $\begin{array}{llll}\text { Oil in Uranium Ash in Uranium } & \\ \text { sample in oil oil in ash } & \text { Location }\end{array}$

number number (percent) (percent) (percent) (percent) Sec., Tp.s R.

Vernal area, Uintah County, Utah

\begin{tabular}{|c|c|c|c|c|c|c|}
\hline VU-1010 & 85728 & 16.0 & 0.00004 & 1.77 & 0.0023 & $25-45-20 E$ \\
\hline VU-1011 & 85729 & 11.4 & 0.00005 & 5.90 & 0.00085 & \\
\hline VU-1012 & 85730 & 3.1 & 0.0002 & 0.96 & 0.021 & " \\
\hline VU-1013 & 85731 & 12.3 & 0.00007 & 6.31 & 0.0011 & $11-4 \mathrm{~S}-2 \mathrm{OE}$ \\
\hline $\mathrm{VU}-10 \mathrm{IL}$ & 85732 & 13.0 & 0.00018 & 3.82 & 0.0047 & P \\
\hline VU-1015 & 85733 & 10.8 & 0.00024 & 3.68 & 0.0066 & $30-4 S-21 E$ \\
\hline Vu $=1016$ & 85734 & 11.6 & 0.00004 & 8.42 & 0.00048 & $31-4 S-2 I E$ \\
\hline VU- 1017 & 85735 & 6.6 & 0.00036 & 1.35 & 0.026 & (8) \\
\hline VU-1018 & 85736 & 10.0 & 0.00002 & 2.66 & 0.00075 & $4-5 S-21 E$ \\
\hline VU-1019 & 85737 & 7.4 & 0.00017 & 3.45 & 0.0049 & $9-5 S-21 E$ \\
\hline vU-1020 & 85738 & 8.0 & 0.00047 & 2.75 & 0,017 & $23-5 S-21 E$ \\
\hline Vv- 1021 & 85739 & 9.4 & $0.0006^{\circ}$ & 3.24 & 0.0018 & $25-55-21 E$ \\
\hline
\end{tabular}

Table 3.-osamples of volcanic and miscellaneous rock types

Field Serial

number number
Equivalent

uranium Uranium Location

(percent) (percent) $\mathrm{Sec}_{0}{ }_{2} \mathrm{Tp},{ }_{2} \mathrm{R}$.

Salmon area, Lemhi County, Idaho

VI-1163 D73717 Psilomelane

$0.001 \quad 0.0004 \quad 27-23 \mathrm{~N}-22 \mathrm{E}$

Challis area, Custer County, Idaho

$\begin{array}{llllll}\text { VI-1157 } & \text { D73714 } & \text { Challis voleanics (green) } & 0.003 & 0.0002 & 29-14 \mathrm{~N}-19 \mathrm{E} \\ \text { VI-1158 } & \text { D73715 } & \text { Challis volcanics (white) } & 0.004 & 0.0004 & \text { " } \\ \text { VI-1159 } & \text { D73716 } & \text { Challis voleanics (brown) } & 0.003 & 0.0003 & \text { " }\end{array}$


Table 3,-oSamples of volcanic and miscellaneous rock types (cont.)

Field Seroial

number numbers

Description

Equivalent

uranium Uranium Location

(percent) (percent) $\mathrm{Sec}_{0}, \mathrm{Tp}_{\circ}, \mathrm{R}_{\circ}$

Continental Divide area, Clark County, Idaho

$\begin{array}{llllll}\text { VI-1076 } 90181 & \text { Silicic volcanic rock } & 0.004 & 0.001 & 19-12 \mathrm{~N}-38 \mathrm{E} \\ \text { VI-1077 } 90182 & \text { Silicic volcanic rock } & 0.002 & 0.000 & 11-14 \mathrm{~N}-38 \mathrm{E}\end{array}$

Driggs area, Teton and Bonneville Counties, Idaho

$\begin{array}{llllll}\text { VI-368a } & \text { D84780 } & \text { Tuff } & 0.004 & 0.0012 & 25-5 \mathrm{~N}-44 \mathrm{E} \\ \text { VI-1096 } & \text { D84787 } & \text { Rhyolite } & 0.004 & 0.0010 & 19-3 \mathrm{~N}-46 \mathrm{E} \\ \text { VI-1152 } & \text { D73713 } & \text { Tuffaceous sandstone } & 0.001 & 0.0004 & 25-3 \mathrm{~N}=44 \mathrm{E}\end{array}$

Caribou Mountains and adjacent areas, Bonneville County, Idaho and Lincoln County, Wyoming

$\begin{array}{lllccc}\text { VI-366a } & \text { D84779 } & \text { Rhyolitic tuff } & 0.003 & 0.0007 & 11-1 \mathrm{~N}-4 \mathrm{OE} \\ \text { VI-369a } & \text { D84781 } & \text { Tuffaceous sand } & 0.004 & 0.0010 & 16-1 \mathrm{~S}-45 \mathrm{E} \\ \text { VI-1081 } & \text { D84786 } & \text { Rhyolitic tuff } & 0.004 & 0.0012 & 8-1 \mathrm{~S}-42 \mathrm{E} \\ \text { VI-1085 } & 90190 & \text { Tuffaceous sand } & 0.004 & -\infty & 16-3 \mathrm{~S}-46 \mathrm{E} \\ \text { VI-1086 } & 90191 & \text { Tuff } & 0.001 & -\infty & \text { "I } \\ \text { VI-1148 } & \text { D73711 } & \text { Pumiceous Ioess } & 0.001 & 0.0003 & 25-2 \mathrm{~N}-43 \mathrm{E} \\ \text { VI-1151 } & \text { D73712 } & \text { Tuff } & 0.002 & 0.0005 & 1-2 \mathrm{~N}-40 \mathrm{E}\end{array}$

Evanston area, Uinta County, Wyoming

$\begin{array}{lllll}\text { VW-1181 D74333 Tuffaceous sandstone } & 0,001 & 0.0007 & 28-16 \mathrm{~N}-120 \mathrm{~W}\end{array}$

Coalville area, Sumit and Morgan Counties, Utah

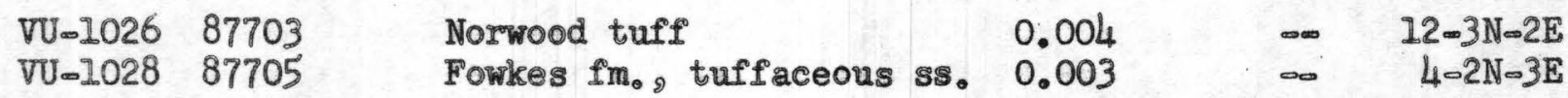

Uinta Mountains area, Duchesne County, Utah

VU-1179 D74331 Red soil from Uinta Mts. 0.004 0.0015 34-1S-9E

Coal Creek anticline area, Rio Blanco County, Colorado

$\begin{array}{llllll}\text { VC-1005 } & 85721 & \text { "Carnotite type" ore } & 0.22 & 0.23 & 22-2 \mathrm{~N}-92 \mathrm{~W} \\ \text { VC-1008 } 85724 & \text { "Carnotite type" ore } & 0.3 & 0.22 & 21-2 \mathrm{~N}-92 \mathrm{~W}\end{array}$

Middle Park area, Grand County, Colorado

VC-1189 D7434I Tuffaceous sandstone

$0.002 \quad 0.0010 \quad 4-3 \mathrm{~N}-80 \mathrm{~W}$ 
Table 3,-oSamples of volcanic and miscellaneous rock types (cont.)

Field Serial number number

Description

Equivalent uranium Uranium Location (percent) (percent) $\mathrm{Sec}_{0} \mathrm{TP}_{0}{ }_{9} \mathrm{R}_{\circ}$

MeCoy area, Eagle County, Colorado

$\begin{array}{llllll}\text { VC-1233 D76839 Green silty shale } & 0.005 & 0.003 & 1-2 S-84 \mathrm{~W}\end{array}$

Porphyry Mountain area, Eagle County, Colorado

$\begin{array}{lllll}\text { VC-1223 D84788 Tuff agglomerate } & 0.002 & 0.0010 & \text { 2-3S } \infty 86 \mathrm{~W}\end{array}$

Glenwood Springs area, Garfield County, Colorado

VC-1004 $85720 \quad$ Red arkosic sandstone $0.002 \quad-\infty \quad 1-6 \mathrm{~S} \times 90 \mathrm{~W}$

Table 4. bosamples of water

Field Serial

Uraniom

Location

number number

Description

(parts per million)

$\mathrm{Sec}_{\circ} \mathrm{Tp}_{\circ}, \mathrm{R}_{\bullet}$

Challis area, Custer County, Idaho

VI-1107 D73710 Spring in Challis voleanies Less than 0.002 28-10N-22E

Caribou Mountains and adjacent areas, Bonneville County, Idaho and Lincoln

County, Wyoming

VW-1100 D73703 Snake River water

$\mathrm{VI}-1103$ D73706 Spring in Wayan $\mathrm{fm}_{0}$ below silicic volcanic rocks

VI-1104 D73707 Spring in Wayan $\mathrm{fm}$ 。 below silicic volcanic rocks

VI-1105 D73708 Spring in Wayan $\mathrm{fm}$ 。 below silicic volcanic rocks

VI-1106 D73709 Hot spring on Fall Creek

Burnt Fork area, Sweetwater County, Wyoming

VW-1234 D76840 Spring below Bishop conglomerate

Bighole Guleh area, Moffat County, Colorado

VCal240 D7684l Spring in Wasateh formation
Less than 0.002

Less than 0.002

$4=37 \mathrm{~N}-117 \mathrm{~W}$

$28-1 \mathrm{~N}-4] \mathrm{E}$

$0.005 \quad 31-2 \mathrm{~N}-4 \mathrm{EE}$

Less than $0,002 \quad 32-2 \mathrm{~N} \times 4$ IE

Less than 0.002

$8-1 N-43 E$

$0,0055 \quad 36-14 \mathrm{~N}-110 \mathrm{~W}$

$0.0065 \quad 29-12 \mathrm{~N}-94 \mathrm{~W}$ 